\section{A simple technique for temporary marking of the electrical stimulation points in brachial plexus injury patients}

Sir, Electrical stimulation of the paralysed muscles in brachial plexus injury patients is commonly practised. Although its effectiveness has not been convincingly proved, many units consider that it may be useful and is practised extensively. Patients and attenders need to be taught the stimulation points. ${ }^{[1]}$ Henna, which is a dye from the plant Lawsonia inermis, has been used to mark the site of the varicose vein perforators. ${ }^{[2]}$

When the home therapy is started a month after surgery, a physiotherapist marks the point of stimulation [Figure 1]. Conventionally, the points are marked by a marker pen, which fades after 1-2 days. When it fades, the patient and attender may get confused about the points of stimulation, with respect to the sides (volar/dorsal), as well as the surfaces (medial/lateral) of the forearm where stimulation has to be delivered.

The physiotherapist after the stimulation session applies henna spots to the points in the limb, where stimulation is to be done. The size of the spots is enough to be visible. The wrist is kept supported on the edge of a tissue box for avoiding the direct contact of henna marking on the forearm and for the markings to dry off. Thereafter, the entire upper limb is gently washed and the pigment is retained temporarily in the dermis ${ }^{[3]}$ [Figure 2] for 7-10 days. After 7 days, when the colour becomes light, the patient retains the spots with a marker pen, till henna is reapplied over the stimulation points once again and gets it checked by the physiotherapist on his next visit.

The benefits of henna are as follows:

1. It allows the patient to take bath with soap and water, and the mark is retained up to 7-10 days

2. The patient does not need to undergo multiple follow-up sessions with the physiotherapist as it is an easy to remember the technique. He/she just needs to confirm the correctness of the location of the points when he/she marks them himself/herself for the first few times

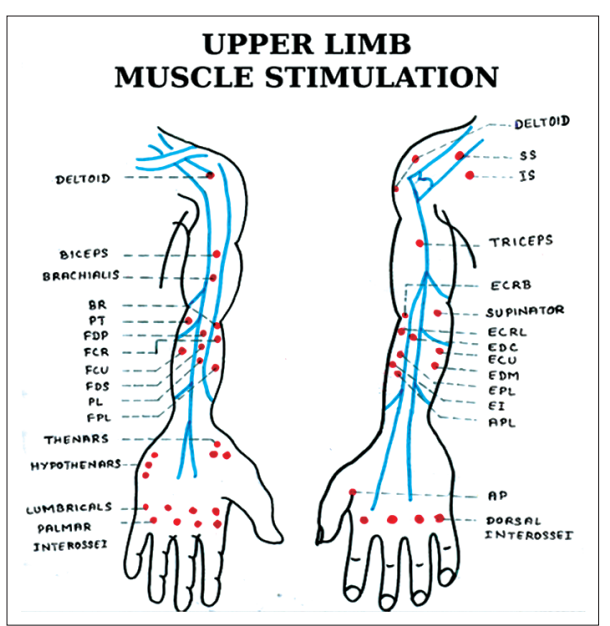

Figure 1: Muscle stimulation chart

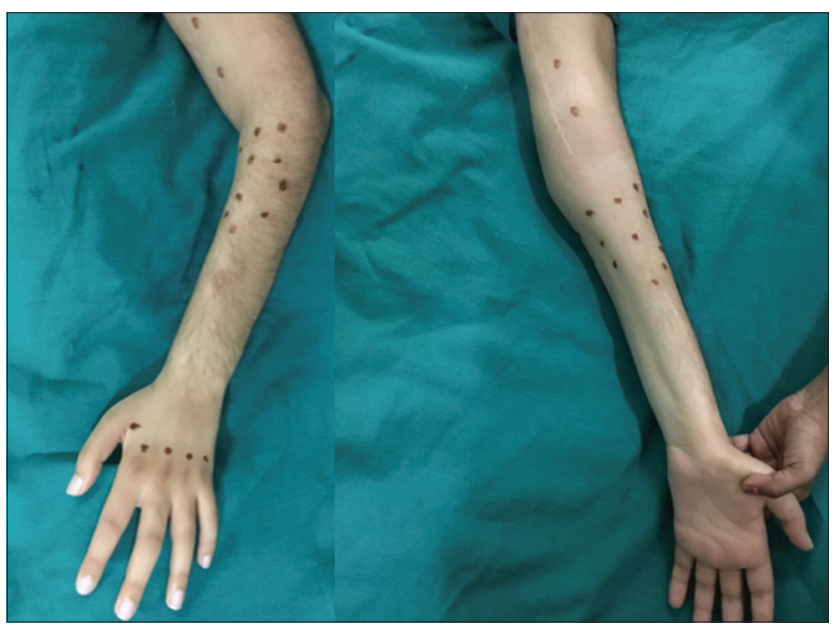

Figure 2: Henna marking of the stimulation points on the left upper limb

3. The temporary red marks are identified better against a brown background by the attender.

Henna application for marking the stimulation points is a simple technique to make it easy for the patient to practice electrical stimulation at home. We found that the compliance rate for electrical muscle stimulation increased when this technique was practised.

\section{Financial support and sponsorship} Nil.

\section{Conflicts of interest}

There are no conflicts of interest.

\section{Karan Rajiv Choudhry, Hari Venkatramani, S. Raja Sabapathy}

Department of Plastic, Hand, Reconstructive Microsurgery and Burns, Ganga Hospital, Coimbatore, Tamil Nadu, India 
Address for correspondence:

Dr. Karan Rajiv Choudhry,

Department of Plastic, Hand, Reconstructive Microsurgery and

Burns, Ganga Hospital, Coimbatore, Tamil Nadu, India.

E-mail: drkc0707asutosh@gmail.com

\section{REFERENCES}

1. Limthongthang R, Muennoi P, Phoojaroenchanachai R, Vathana T, Wongtrakul S, Songcharoen P, et al. Effectiveness and safety of home-based muscle electrical stimulator in brachial plexus injury patients. J Med Assoc Thai 2014;97 Suppl 9:S56-61.

2. Puri VA, Mahendru S, Rana RE. Use of henna as a skin marker. J Plast Reconstr Aesthet Surg 2006;59:1123-4.

3. Kazandjieva J, Grozdev I, Tsankov N. Temporary henna tattoos. Clin Dermatol 2007;25:383-7.

This is an open access article distributed under the terms of the Creative Commons Attribution-NonCommercial-ShareAlike 3.0 License, which allows others to remix, tweak, and build upon the work non-commercially, as long as the author is credited and the new creations are licensed under the identical terms.

\begin{tabular}{|l|l|}
\hline \multicolumn{2}{|c|}{ Access this article online } \\
\hline Quick Response Code: & Website: \\
\hline & www.ijps.org \\
\cline { 2 - 2 } & \\
\hline
\end{tabular}

How to cite this article: Choudhry KR, Venkatramani $\mathrm{H}$, Sabapathy SR. A simple technique for temporary marking of the electrical stimulation points in brachial plexus injury patients. Indian J Plast Surg 2017; 50:316-7.

(ㄷ) 2017 Indian Journal of Plastic Surgery | Published by Wolters Kluwer - Medknow 